\title{
Endometrial cancer following endometrial resection
}

\author{
Giorgia Gaia • Revaz Botchorishvili • Michel Canis • \\ Benoit Rabischong • Kris Jardon • \\ Juan Raul Escalona • Guy Lesec • \\ Frederic Penault-Llorca • Pierre Dechelotte • \\ Jean Luc Pouly • Gérard Mage
}

Received: 25 October 2006 / Accepted: 5 April 2007 / Published online: 8 May 2007

(C) Springer-Verlag 2007

\begin{abstract}
Endometrial ablation has emerged as a viable alternative to hysterectomy in the treatment of medically intractable dysfunctional uterine bleeding. However, this procedure cannot guarantee complete removal of the entire endometrium. Cases of endometrial cancer after endometrial ablation have been reported in the literature. We reviewed the cases of patients who underwent hysteroscopic endometrial ablation by endometrial resection for abnormal uterine bleeding from 1994 to 2005 at the Department of Obstetrics and Gynecology, Polyclinique, Clermont-Ferrand University. Of the 3769 patients having had hysteroresections, four developed endometrial cancer after complete endometrial ablation (1.06 out of 1000). All four of these
\end{abstract}

G. Gaia $(\bowtie) \cdot$ R. Botchorishvili $\cdot$ M. Canis $\cdot$ B. Rabischong $\cdot$

K. Jardon · J. R. Escalona $\cdot$ J. L. Pouly $\cdot$ G. Mage

Department of Obstetrics and Gynecology,

Polyclinique de l'Hôtel-Dieu, CHU Clermont-Ferrand,

Université d'Auvergne,

Boulevard Leon Malfreyt,

63058 Clermont-Ferrand, Cedex1, France

e-mail: gaiagiorgia3@libero.it

G. Lesec

Institute of Anatomy and Pathological Cytology,

2, av Victoria,

03200 Vichy, France

F. Penault-Llorca

Centre Jean Perrin,

58, rue Montalembert, B.P. 392, 63011 Clermont-Ferrand, France

P. Dechelotte

Department of Pathological Anatomy, CHU Clermont-Ferrand,

Université d'Auvergne,

Boulevard Leon Malfreyt,

63058 Clermont-Ferrand, Cedex1, France patients showed histological evidence of endometrial polyps at endometrial resection, and all of them presented risk factors for endometrial carcinoma, such as obesity and/or arterial hypertension. Endometrial cancer after hysteroscopic endometrial ablation is a rare but possible occurrence, even a long time after the operation. Close monitoring of patients who have undergone endometrial ablation for endometrial polyps and who present risk factors, such as obesity or hypertension, even after apparent total ablation of the endometrium is strongly recommended, independently of the presence of abnormal bleeding that can represent a late symptom of advanced endometrial cancer.

Keywords Endometrial ablation - Endometrial carcinoma . Endometrial polyps $\cdot$ Endometrial resection

\section{Introduction}

Endometrial ablation has emerged as a viable alternative to hysterectomy in the treatment of medically intractable dysfunctional uterine bleeding for women who have no desire to preserve their fertility or for the treatment of postmenopausal bleeding associated with benign endometrial or myometrial pathology [1-12]. The principle of the technique is to remove the whole thickness of the endometrium and some of the superficial myometrium to ensure complete removal of the endometrial basal glands, using a monopolar or bipolar resecting loop or coagulating electrode ("roller-ball"). However, despite the theoretically complete ablation of the endometrium, cases of endometrial cancer (EC) after endometrial ablation have been described in the literature [13-22]. 
To study this problem, we have reviewed the cases of patients who underwent hysteroscopic endometrial ablation by endometrial resection for abnormal uterine bleeding from 1994 to 2005 at the Department of Obstetrics and Gynecology, University Hospital of Clermont-Ferrand (Auvergne region, France).

\section{Subjects and methods}

A retrospective chart review was completed for all patients who underwent hysteroscopic endometrial ablation by endometrial resection between January 1994 and December 2005 in the Department of Obstetrics and Gynecology of the University Hospital of Clermont-Ferrand (Auvergne region, France). A search of the computerized hospital records identified the 3769 patients who form the basis for this study. A retrospective chart review was completed for all patients who developed EC between 1994 and 2005. Patients with EC were identified from the computerized records maintained by the public and private pathology departments of Auvergne region on the basis of current procedural terminology codes. A total of 852 patients were identified with EC. By matching the lists and a manual review of the schedules, four patients were identified as having developed EC after hysteroscopic endometrial ablation by endometrial resection (Table 1).

\section{Case reports}

Case 1

A 63-year-old postmenopausal woman, gravida 2, para 1, one cesarean section, presented for metrorrhagia in March 1995. She was had been taking hormone replacement therapy (HRT) in continuous regimen with Oestrogel (estradiol) + Utrogestan (natural progesterone) for 8 years.
The patient had presented several episodes of spotting in 1992, 1993 and 1994 and had had ultrasonographic imaging checks with no associated treatment. Her past medical history included treated arterial hypertension (AH). The patient's body mass index (BMI) was 21 .

In March 1995 the ultrasonography showed an endometrium of $8 \mathrm{~mm}$ with the suspicion of endometrial polyp and sub-mucosal myoma. In April 1995 the patient underwent hysteroscopic resection of an endometrial polyp and submucosal myoma by monopolar resecting loop followed by complete endometrial ablation with monopolar resecting loop, even though the endometrium appeared normal at hysteroscopy. The histopathology was consistent with an endometrial fibro-glandular polyp and leiomyoma without any signs of malignancy and endometrium without anything out of the ordinary.

Following the endometrial ablation she continued the same HRT for 10 years up to 2005 when she presented again for metrorrhagia. Hysteroscopy was performed in August 2005 and showed the presence of an endometrial polyp and diffuse endometrial hypertrophy. Histopathological results after curettage revealed well-differentiated EC with clear cells.

In October 2005 she underwent laparoscopic total hysterectomy, bilateral salpingoophorectomy and bilateral pelvic lymphadenectomy followed by external radiotherapy. The final histological diagnosis was: moderately to poorly differentiated endometrioid adenocarcinoma with $10 \%$ of clear cells infiltrating $50 \%$ of the myometrium without embols. FIGO stage: IB, GII-III.

\section{Case 2}

A 60-year-old postmenopausal woman, gravida 0, presented in October 1997 for metrorrhagia that had started 8 months before. She was not under HRT. She presented an episode of spotting in 1992 and underwent curettage. The

Table 1 Data on the four patients who developed EC after hysteroscopic endometrial ablation by endometrial resection

\begin{tabular}{|c|c|c|c|c|c|c|c|}
\hline \multirow{2}{*}{$\begin{array}{l}\text { Number } \\
\text { of case }\end{array}$} & \multirow{2}{*}{$\begin{array}{l}\text { Age of } \\
\text { menopause } \\
\text { (years) }\end{array}$} & \multirow{2}{*}{$\begin{array}{l}\text { Age at cancer } \\
\text { diagnosis } \\
\text { (years) }\end{array}$} & \multirow{2}{*}{$\begin{array}{l}\text { Interval from endometrial } \\
\text { ablation to carcinoma diagnosis } \\
\text { (years) }\end{array}$} & \multirow[t]{2}{*}{ Parity } & \multicolumn{3}{|l|}{ Risk factors ${ }^{\mathrm{a}}$} \\
\hline & & & & & History & BMI & HRT \\
\hline 1 & 53 & 73 & 10 & $\mathrm{G} 2 \mathrm{P} 2$ & $\mathrm{AH}$ & 21 & $\begin{array}{l}\text { Yes, at hysteroscopy } \\
\text { and after hysteroscopy }\end{array}$ \\
\hline 2 & 40 & 68 & 8 & G0P0 & $\mathrm{AH}$ & 33 & No \\
\hline 3 & 50 & 58 & 5 & $\mathrm{G} 2 \mathrm{P} 2$ & $\begin{array}{l}\text { AH, Hyper- } \\
\text { cholesterolemia }\end{array}$ & 39 & $\begin{array}{l}\text { Yes, at hysteroscopy, } \\
\text { stoped after } \\
\text { hysteroscopy }\end{array}$ \\
\hline 4 & 57 & 62 & 6 & $\mathrm{G} 2 \mathrm{P} 2$ & Hypothyroidism & 34 & Yes, after hysteroscopy \\
\hline
\end{tabular}

${ }^{\text {a }} \mathrm{AH}$, Arterial hypertension; BMI, body mass index; HRT, hormone replacement therapy

${ }^{\mathrm{b}}$ BMI categories: underweight $=<18.5$; normal weight $=18.5-24.9$; overweight $=25-29.9$; obesity $=$ BMI of 30 or greater 
histopathological result of the material obtained was benign. The patient's medical history included AH and obesity (BMI: 33).

In September 1997 the ultrasonography showed an endometrium of $10 \mathrm{~mm}$. In October 1997 an hysteroscopy revealed two voluminous endometrial polyps, one of which showed a suspicious area near the pedicle. Selective resection of the polyps by monopolar resecting loop was performed, followed by endometrial complete curettage. The histopathology was consistent with glandulo-cystic polyps without any malignancy, and atrophic endometrium.

In August 2005 she presented again for severe metrorrhagia. She underwent magnetic resonance imaging (MRI) that revealed the presence of a heterogeneous endometrial lesion throughout the cavity which had infiltrated the myometrium. The hysteroscopy performed in August 2005 showed the presence of two suspicious polypous lesions. The histopathological result of curettage showed moderately differentiated endometrioid adenocarcinoma developed in the polypoid endometrium.

In September 2005 she underwent laparotomy for total hysterectomy and bilateral salpingoophorectomy. A lymphadenectomy was not performed due to technical difficulties (obesity). The patient also had external radiotherapy. The final diagnosis was well-differentiated endometrioid adenocarcinoma infiltrating more than $50 \%$ of the myometrium. FIGO stage: IC, GI.

\section{Case 3}

A 53-year-old postmenopausal woman, gravida 3, para 2, one abortion, presented for metrorrhagia in January 2000. She had been under combined HRT (Climene) for 3 years. The patient's past medical history included medically treated AH, hypercholesterolemia and obesity (BMI: 39). A hysterography was performed that revealed the presence of two endometrial polyps.

In April 2000 she underwent resection of the polyps followed by complete resection of the endometrium by monopolar resecting loop followed by "roller-ball" coagulation of the whole endometrial cavity. The histopathology was consistent with glandulo-cystic polyps without any signs of malignancy. Subtle adenomyosis was also observed.

In December 2004 she presented again for metrorrhagia. HRT was stopped. Hysterography showed suspicious intrauterine images. In March 2005 another hysteroscopy was carried out, when a non-suspicious endometrial hyperplasia was resected by bipolar loop (Versapoint, Gynecare). The pathological report described well-differentiated endometrioid intra-epithelial adenocarcinoma.

In April 2005 she underwent laparoscopic total hysterectomy, bilateral salpingoophorectomy with bilateral pelvic lymphadenectomy. Then she had brachitherapy. The final diagnosis was well-differentiated adenocarcinomaadenoacanthoma without myometrial invasion. FIGO stage: IA, GI.

Case 4

A 56-year-old woman, gravida 2, para 2, presented in September 1993 for metrorrhagia persisting for 7 months. She was not under HRT as she was still regularly menstruating. The patient's medical history included obesity (BMI: 34) and hypothyroidism. An hysterography was performed that resulted in the suspected presence of endometrial polyps and adenomyosis.

In September 1993 an hysteroscopy showed a hypotrophic endometrium with areas of hyperplasia. The uterine fundus had a petecchial appearance, suggestive of the presence of adenomyosis. Complete resection of the endometrium by monopolar resecting loop was carried out. The pathology result was consistent with simple polypoid hyperplasia without any malignancy.

In October 1994 she started HRT with Oestrogel (estradiol) 25 days/month + Luteran 5 (chlormadinone) 12 days/month. In June 1996 she underwent an uterine ultrasonographic imaging examination that gave normal results. In January 1999 she presented again for metrorrhagia. HRT was stopped. An ultrasonography in May 1999 was repeated and showed a $15-\mathrm{mm}$ endometrium. An endometrial biopsy revealed a well-differentiated endometrial adenocarcinoma.

In July 1999 she underwent laparoscopic total hysterectomy, bilateral salpingoophorectomy with pelvic bilateral lymphadenectomy, this was followed by brachytherapy. The final diagnosis was well-differentiated endometrioid adenocarcinoma infiltrating less than $50 \%$ of the myometrium. FIGO stage: IB, GI.

The clinical and technical aspects of these four patients are presented in Table 2.

\section{Discussion}

EC after endometrial ablation is a rare but possible occurrence, as described in the literature in a number of case reports [13-22]. The exact rate of EC after endometrial ablation is still unknown, but the most common symptom is recurrent abnormal bleeding and the state of cancer diagnosed is advanced in many of the cases described $[14,16-20]$.

The lifetime risk of EC in the general population is considered to be $2-3 \%$, and the prevalence to be 1 in 1000 . In our study, four patients of 3769 reviewed developed EC after complete endometrial ablation (1.06 out of 1000). We are aware that the rate presented is probably biased by the 
Table 2 Clinical and technical aspects of the four cases

\begin{tabular}{|c|c|c|c|c|c|}
\hline $\begin{array}{l}\text { Number } \\
\text { of case }\end{array}$ & Endometrial ablation method & $\begin{array}{l}\text { Circumstances } \\
\text { of cancer } \\
\text { diagnosis }\end{array}$ & $\begin{array}{l}\text { Histology at } \\
\text { hysteroscopy }\end{array}$ & $\begin{array}{l}\text { Histology of cancer, } \\
\text { stage and grade }\end{array}$ & $\begin{array}{l}\text { Treatment for } \\
\text { pathologic diagnosis }\end{array}$ \\
\hline 1 & $\begin{array}{l}\text { Polyp resection }+ \text { myoma resection }+ \\
\text { complete endometrial resection }\end{array}$ & $\begin{array}{l}\text { Recurrent } \\
\text { bleeding } \\
\text { under HRT }\end{array}$ & $\begin{array}{l}\text { Fibro glandular } \\
\text { polyp and myoma }\end{array}$ & $\begin{array}{l}\text { Adeno carcinoma } \\
\text { with clear cells 1B, } \\
\text { Grade II-III }\end{array}$ & $\begin{array}{l}\mathrm{TH}+\mathrm{BSO}+ \\
\text { lymphadenectomy } \\
\text { by laparoscopy }+ \\
\text { Rx therapy }\end{array}$ \\
\hline 2 & $\begin{array}{l}\text { Selective resection of polyps }+ \\
\text { curettage }\end{array}$ & $\begin{array}{r}\text { Recurrent } \\
\text { bleeding }\end{array}$ & $\begin{array}{l}\text { Two glandulo-cystic } \\
\text { polyps }+ \text { endometrial } \\
\text { atrophy }\end{array}$ & $\begin{array}{l}\text { Adeno carcinoma } \\
\text { 1C, Grade I }\end{array}$ & $\begin{array}{l}\mathrm{TH}+\mathrm{BSO}+ \\
\text { lymphadenectomy } \\
\text { by laparotomy }+ \\
\text { Rx therapy }\end{array}$ \\
\hline 3 & $\begin{array}{l}\text { Polyp resection + complete } \\
\text { endometrial resection + "roller-ball" } \\
\text { endometrial coagulation }\end{array}$ & $\begin{array}{r}\text { Recurrent } \\
\text { bleeding }\end{array}$ & $\begin{array}{l}\text { Three glandulo- } \\
\text { cystic polyps }+ \\
\text { adenomyosis }\end{array}$ & $\begin{array}{l}\text { Adeno acanthoma } \\
1 \mathrm{~A}, \text { Grade I }\end{array}$ & $\begin{array}{l}\text { TH+BSO }+ \\
\text { lymphadenectomy } \\
\text { by laparoscopy }+ \\
\text { Rx therapy }\end{array}$ \\
\hline 4 & Complete endometrial resection & $\begin{array}{l}\text { Recurrent } \\
\text { bleeding } \\
\text { under HRT }\end{array}$ & $\begin{array}{l}\text { Simple polypoid } \\
\text { hyperplasia }\end{array}$ & $\begin{array}{l}\text { Adeno carcinoma } \\
\text { 1B, Grade I }\end{array}$ & $\begin{array}{l}\mathrm{TH}+\mathrm{BSO}+ \\
\text { lymphadenectomy } \\
\text { by laparoscopy }+ \\
\text { Rx therapy }\end{array}$ \\
\hline
\end{tabular}

HRT, Hormone replacement therapy; TH, total hysterectomy; BSO, bilateral salpingo ophorectomy

fact that we did not check whether the patients who underwent endometrial resection in Auvergne have been treated for EC outside the region. In addition, even those studies using a questionnaire and cancer registries were unable to reach the completeness of the database [22]. However, our goal was not to establish a rate but to determine whether the patents who developed EC after endometrial resection presented any risk factors. Nevertheless, our data give an approximation of the incidence for EC after complete endometrial resection and should serve as a guide for patient counseling on the risks of hysteroscopic resection and the necessity of specific follow-up. The occurrence of EC after endometrial ablation also raises the question whether this finding can be correlated to the technique of endometrial ablation, the pathology itself or other factors.

Endometrial ablation is widely performed as an alternative to hysterectomy in the treatment of uterine bleeding associated with benign endometrial or myometrial pathology [1-12]. Serious short-term and long-term complications of endometrial ablation have been described. These include uterine perforation, fluid overload, fatal air embolism and thermal and mechanical damage to the bowel, bladder, ureter, pelvic blood vessels and hematometra [11, 24, 25]. Patients who have undergone endometrial ablation can also be at risk for pregnancy as residual functional islands of endometrial tissue can persist following the procedure. Even with complete amenorrhea, the risk of pregnancy is not absent [26-28]. Several studies have shown the persistence of endometrium even after complete endome- trial resection, so it is conceivable that some woman may develop adenocarcinoma [1, 5, 29-31].

Khastgir et al. [29] studied 12 women with continuing menstrual problems after endometrial ablation by means of transvaginal ultrasound imaging and reported unchanged endometrium in four women and minimal residual endometrium in five women. Turnbull et al. [30], using magnetic resonance imaging, described the presence of residual endometrium after endometrial resection after a mean interval of 16 months in all except for three amenorrhoeic women, with similar mean endometrial volume present in menstruating and amenorrhoeic groups. Histology of the subsequent hysterectomy specimens confirmed the presence of endometrium and adenomyosis and revealed extensive fibrosis and a necrotic granulomatous reaction.

These nests of tissue missed during hysteroscopic endometrial ablation might later develop into a blind pocket of EC while at the same time synechiae and superficial scar formation could delay bleeding and the subsequent diagnosis of carcinoma. It is also conceivable that some women may develop adenocarcinoma in deep remains of adenomyosis not adequately destroyed by superficial ablation [11]. In our study, adenomyosis was found only in one patient of the four after endometrial resection.

In all of the cases described in the literature except two [13-22], the endometrial ablation was performed by rollerball coagulation. In our study, complete endometrial ablation by resecting loop was performed in three of the four cases (one of these three cases had endometrial resection by 
monopolar resecting loop followed by monopolar "rollerball" coagulation of the uterine cavity), while in the remaining one case complete endometrial polyps resection was performed by resecting loop followed by complete curettage of the uterine cavity. This finding emphasizes the fact that the occurrence of EC after endometrial ablation is related not only to the technique chosen but also to other factors.

All four patients of our study showed histological evidence of endometrial polyps at endometrial resection, and two of these later presented with cancer that had developed in endometrial polyps. Endometrial polyps are common pathological lesions of the uterine corpus and are usually found in perimenopausal woman [32, 33]. Abnormal uterine bleeding is frequently the presenting symptom, but polyps are often asymptomatic and found during routine ultrasound or infertility investigations [34]. Polyps are in general benign growths, although malignancy confined to a polyp has also been identified [35-37]. Polyps have also been described to be associated with premalignant changes of the endometrium, but their role as precursors for endometrial carcinoma has not been established [36-40]. In all four of the cases we describe here, the histopathology within the polyps treated during the resection did not revealed any premalignant or malignant changes.

According to the literature, the development of endometrial polyps and of endometrial cancer share the same risk factors. Reslova et al. [40] showed that AH associated with obesity appears to be an important factor, which may play a role in the pathogenesis of polyps. The correlation between overweight, body fat and higher levels of estrogen have been described in other studies [41]. Savelli et al. [36] found that out of a panel of clinical characteristics, only patient age, menopausal status and $\mathrm{AH}$ seemed to be statistically associated with premalignant and malignant polyps. It has also been reported that endometrial polyps are characterized by aberrations of specific chromosome regions that probably involve genes related to the proliferative process [42-44].

$\mathrm{AH}$ is an well-established risk factor for female hormone-related cancers (such as adenocarcinoma of the endometrium) [45-52]. Most studies that address this question have found that the risk increases with the duration of the hypertension, particularly when diagnosed before the age of 50 years [51, 52]. The high BMI and hypertension appear to have a synergistic effect on the risk of endometrial cancer and produce an appreciably elevated risk (almost five-fold) in women exposed to both factors [53].

All of the patients in our group presented at least one of these risk factors: one patient presented only with obesity, one presented only with $\mathrm{AH}$ and two presented with both obesity and AH. Even if all of the polyps were to be completely removed during the hysteroscopy, these risk factors persist after surgery. The persistence of risk factors shared with endometrial cancer exposed these patients to a major global risk of developing an endometrial cancer even a long time after the hysteroresection (mean time in our study: 7 years, minimum: 5 years, maximum: 10 years).

The long delay between endometrial ablation and the diagnosis of endometrial cancer in our study, together with the lack of early occurrence of endometrial cancer after the surgical procedure, confirmed the diagnostic value of hysteroresection followed by pathological examination. No potentially malignant lesions were missed.

\section{Final remarks}

This study and the review of the literature show that endometrial cancer after endometrial ablation is a rare but possible occurrence, whether the technique is performed by "roller-ball" coagulation or by resecting loop. The patients with endometrial polyps at resection may present a higher risk for developing endometrial cancer. The occurrence of endometrial cancer may come a long time after endometrial ablation, and the recurrent bleeding may become evident when the cancer stage is already advanced. Even when hysteroresection appears to be complete from the surgical point of view, the procedure cannot guarantee complete removal of the entire endometrium as some endometrial pockets are always left in the cavity. The induction of scars and synechia may mask both physiological and pathological bleeding. Therefore, patients with amenorrhea or hypomenorrhea who have undergone hysteroresection due to endometrial polyps, even after complete ablation of the polyps and apparent total removal of the endometrium, must be considered at higher risk of development of endometrial cancer than the general population, especially in the presence of the additional factors of hypertension and obesity and in the case of associated HRT. For these reasons we suggest that the follow-up after endometrial resection of the patients with these risk factors must include systematic annual ultrasonographic checks. Should the ultrasonographic results be suspicious, hysteroscopy is strongly recommended. If hysteroscopy is difficult to perform due to intrauterine adhesions, hysterectomy may be recommended.

\section{References}

1. De Cherney AH, Desmond MC, Lavy G, Polan ML (1987) Endometrial ablation for intractable uterine bleeding: Hysteroscopic resection. Obstet Gynaecol 78:668-670

2. Vancaillie TG (1989) Electrocoagulation of the endometrium with the ball-end resectoscope. Obstet Gynaecol 74:425-427

3. Rutherford AJ, Glass MR (1990) Management of menorrhagia. Br Med J 301:290-291 
4. Serden SP, Brooks PG (1991) Treatment of abnormal uterine bleeding with the gynaecologic resectoscope. J Reprod Med 36:697-699

5. Ke RW, Taylor PJ (1991) Endometrial ablation to control excessive uterine bleeding. Hum Reprod 6:574-580

6. Magos AL, Baumann R, Lockwood GM, Turnbull AC (1991) Experience with the first 250 endometrial resection for menorrhagia. Lancet 334:1074-1078

7. Dwyer N, Hutton J, Stirrat GM (1993) Randomised trial comparing endometrial resection with abdominal hysterectomy for the surgical treatment of menorrhagia. Br J Obstet Gynaecol 100:237-243

8. Sculpher MJ, Bryan S, Dwyer N, Hutton J, Stirrat GM (1993) An economic evaluation of transcervical endometrial resection versus abdominal hysterectomy for the treatment of menorrhagia. $\mathrm{Br} \mathbf{J}$ Obstet Gynaecol 100:244-252

9. Broadbent JA, Magos AL (1993) Transcervical resection of the endometrium (TRCE). In: Sutton C, Diamond MP (ed) Endoscopic Surgery for Gynaecologists. WB Sauders, London, pp 294-300

10. Pinion SB, Parkin DE, Abramovich DR (1994) Randomised trial of hysterectomy, endometrial laser-ablation and transcervical endometrial resection for dysfunctional uterine bleeding. Br Med J 309:979-983

11. Garry R (1995) Good practice with endometrial ablation. Obstet Gynaecol 86:144-151

12. Raiga J, Mage G, Glowaczower E (1995) Factors affecting risk of failure after endometrial resection. J Gynecol Surg 11:1-6

13. Dwyer NA, Stirrat GM (1991) Early endometrial carcinoma: An incidental finding after endometrial resection. $\mathrm{Br} \mathrm{J}$ Obstet Gynaecol 98:733-734

14. Copperman AB, DECherney AH, Olive DL (1993) A case of endometrial cancer following endometrial ablation for dysfunctional uterine bleeding. Obstet Gynaecol 82:640-642

15. Ramey JM, Koonings PP, Given FT, Acosta AA (1994) The process of carcinogenesis for endometrial adenocarcinoma could be short: development of a malignancy after endometrial ablation. Am J Obstet Gynaecol 170:1370-1371

16. Horowitz IR, Copas PR, Aaronoff M (1995) Endometrial adenocarcinoma following endometrial ablation for postmenopausal bleeding. Gynaecol Oncol 56:460-463

17. Margolis MT, Thoen LD, Boike GM (1995) Asymptomatic endometrial carcinoma after endometrial ablation. Int $\mathrm{J}$ Gynaecol Obstet 51:255-258

18. Baggish MS, Ringgenberg E, Sze EHM (1995) Adenocarcinoma of the corpus uteri following endometrial ablation. J Gynecol Surg 11:91-94

19. Iqbal PK, Paterson MEL (1997) Endometrial carcinoma after endometrial resection for menorrhagia. $\mathrm{Br} \mathrm{J}$ Obstet Gynaecol 104:1097-1098

20. Klein Z, Markovitch O, Altaras M, Beyth Y, Fishman A (1997) Advanced endometrial adenocarcinoma following endometrial ablation: a case report and review of the literature. Int J Gynecol Cancer 7:163-165

21. Gizelle N, Brooks Carter GN, Mauren A, Killackey MA, Robert S, Neuwirth RS (2000) Adenocarcinoma of the endometrium after endometrial ablation. Obstet Gynaecol 96:836-837

22. Neuwirth RS, Loffer FD, Trenhaile T, Levin B (2004) The incidence of endometrial cancer after endometrial ablation in a low-risk population. J Am Assoc Gynecol Laparosc 11:492-494

23. Lurain JR (1996) Uterine cancer. In: Berek JS, Adashi EY, Hillard PA (ed) Novak's gynaecology, 12th edn. Williams and Wilkins, Baltimore, pp 1057-1110

24. Dwer N, Fox R, Mills M, Hutton J (1991) Haematometra caused by hormone replacement therapy after endometrial resection. Lancet 338:1205

25. Istre O, Skajaa K, Schjoensby AP, Forman A (1992) Changes in serum electrolytes after trancervical resection of endometrium and submucous fibroids with use of glycine $1.5 \%$ for uterine irrigation. Obstet Gynecol 80:218-222

26. Mongelli JM, Evans AJ (1991) Pregnancy after transcervical endometrial resection. Lancet 338:733-734

27. Whitelaw NL, Garry R, Sutton CJG (1992) Pregnancy following endometrial ablation: 2 Case reports. Gynaecol Endosc 1:129-132

28. Wood C, Rogers P (1993) A pregnancy after planned partial endometrial resection. Aust N Z J Obstet Gynaecol 33:316-318

29. Khastgir G, Mascarenhas LJ, Shaxted EJ (1993) The role of transvaginal ultrasonography in preoperative case selection and postoperative follow-up of endometrial resection. $\mathrm{Br} \mathrm{J}$ Radiol 66:600-604

30. Turnbull LW, Jumaa A, Bowsley SJ, Dhawan S, Horsman A, Killick SR (1997) Magnetic resonance imaging of the uterus after endometrial resection. Br J Obstet Gynaecol 104:934-938

31. McCausland AM (1992) Hysteroscopic myometrial biopsy: its use in diagnosing adenomyosis and its clinical application. Am J Obstet Gynaecol 166:1619-1628

32. Schlaen I, Bergeron C, Ferenczy A, Wong P, Naves A (1988) Endometrial polyps: a study of 204 cases. Surg Pathol 1:375-382

33. Clevenger-Hoeft M, Syrop CH, Stovall DW, Van Voorhis BJ (1999) Sonohysterography in premenopausal women with and without abnormal bleeding. Obstet Gynecol 94:516-520

34. Orvieto R, Bar-Hava I, Dicker D, Bar J, Ben-Rafael Z, Neri A (1999) Endometrial polyps during menopause: characterization and significance. Acta Obstet Gynecol Scand 78:883-886

35. Anastasiadis PG, Koutlaki NG, Shaphida PG, Galazios GC, Tsikouras PN, Liberis VA (2000) Endometrial polyps:prevalence, detections and malignant potential in women with abnormal uterine bleeding. Eur J Gynaecol Oncol 21:180-183

36. Savelli L, De Iaco P, Santini D, Rosati F, Ghi T, Pignotti E, et al (2003) Histopathologic features and risk factors for benignity, hyperplasia and cancer in endometrial polyps. Am J Obstet Gynaecol 188:927-931

37. Ben Arie, Goldchmit C, Laviv Y, et al (2004) The malignant potential of endometrial polyps. Obstet Gynaecol 115:206-210

38. Bakour SH, Khan KS, Gupta JK (2000) The risk of premalignant and malignant pathology in endometrial polyps. Acta Obstet Gynecol Scand 79:317-320

39. Armenia CS (1967) Sequential relationship between endometrial polyp and carcinoma of endometrium. Obstet Gynecol 30:524-529

40. Reslova T, Tosner J, Rels M, Kugler R, Vavrova I (1999) Endometrial polyps: a clinical study of 245 cases. Arch Gynecol Obstet 262:133-139

41. DeWaay DJ, Syrop CH, Nygaard IE, Davis WA, Van Voorhis BJ (2002) Natural history of uterine polyps and leiomyomata. Obstet Gynecol 100:3-7

42. Speleman F, Cin PD, Van Roy N, et al (1991) Is t(6;20)(p21;q13) a characteristic chromosome change in endometrial polyps? Genes Chromosomes Cancer 3:318-319

43. Dal Cin P, De Wolf F, Klerckx P, Van den Berghe H (1992) The 6 p21 chomosome region is nonrandomly involved in endometrial polyps. Gynaecol Oncol 46:393-96

44. Vanni R, Dal Cin P, Marras S et al (1993) Endometrial polyp: another benign tumor characterized by $12 q 13-q 15$ changes. Cancer Genet Cytogenet 68:32-33

45. Dyer AR, Stamler J, Berkson DM, Lindberg HA, Stevens E (1975) High blood-pressure: a risk factor for cancer mortality? Lancet 1:1051-1056

46. Soler M, Chatenoud L, Negri E, Pirazzini F, Franceschi S, La Vecchia C (1999) Hypertension and hormone-related neoplasms in women. Hypertension 34:320-325

47. Hamet P (1997) Cancer and hypertension: a potential for crosstalk? J Hypertens 15:1573-1577

48. Parazzini F, La vecchia S, Bocciolone L, Franceschi S (1991) The epidemiology of endometrial cancer. Gynaecol Oncol 41:1-10 
49. Svardsudd K, Tibblin G (1979) Mortality and morbidity during 13.5 years' follow-up in relation to blood pressure. Acta Med Scand 205:483-92

50. Raynor WR Jr, Shekelle RB, Rossof AH, Maliza C, Paul O (1981) High blood pressure and 17-year cancer mortality in the Western Electric Health Study. Am J Epidemiol 113:371-377

51. Maatela J, Aromas A, Salmi T, Pohja M, Vuento M, Gronroos M (1994) The risk of endometrial cancer in diabetic and hypertensive patients: a nationwide record- linkage study in Finland. Ann Chir Gynaecol 83:20- 4

52. Inoue $\mathrm{M}$, Okayama $\mathrm{A}$, Fujita $\mathrm{M}$, Enomoto $\mathrm{T}$, Tanizawa $\mathrm{O}$, Ueshima H (1994) A case- control study on risk factors for uterine endometrial cancer in Japan. Jpn J Cancer Res 85: $346-350$

53. Rothman KJ, Greenland S, Walker AM (1980) Concepts of interaction. Am J Epidemiol 112:467-470 